\title{
Estimation of the frost resistance of the strawberry
}

\section{Zoya Ozherelieva, Pavel Prudnikov, and Marina Zubkova}

Russian Research Institute of Fruit Crop Breeding (VNIISPK), Zhilina, Oryol Region, 302530, Russian Federation

Address correspondence and requests for materials to Zoya Ozherelieva, ozherelieva@vniispk.ru

\begin{abstract}
As a result of the experiment, it was found that an increase in bound water and a decrease in free water in the leaves in the autumn are characteristic of strawberry plants against the background of a decrease in the level of total water content. The maximum ratio of bound water to free water based on the accumulation of sucrose and the amino acid proline was established in such varieties as 'Solovushka', 'Tsaritsa', 'Sara' and 'Korona'. A high level of correlation was noted between the minimum air temperature and physiological and biochemical indicators of the formation of frost resistance of strawberries. A high correlation was established between the degree of freezing tolerance of strawberry plants and the fractional composition of water at the beginning of winter. In the early winter, the frost-resistant strawberry varieties 'Solovushka', 'Rosinka', 'Tsaritsa', 'Korona' and 'Sara' were characterized. The ability to stably maintain frost resistance during the winter thaw was shown by the varieties 'Solovushka', 'Tsaritsa' and 'Korona'. As a result of the studies, frost-resistant strawberry varieties - 'Solovushka', 'Tsaritsa' and 'Korona' — were isolated.
\end{abstract}

Keywords: strawberry, varieties, fractional composition of leaf water, sucrose, proline, artificial freezing, frost resistance

\section{Introduction}

The strawberry is a leading commercial berry crop. It rightfully takes first place in the world among berry crops, thanks to its excellent taste, attractive appearance

Citation: Ozherelieva, Z., Prudnikov, P., and Zubkova, M. 2020. Estimation of the frost resistance of the strawberry. Bio. Comm. 65(4): 288-296. https://doi. org/10.21638/spbu03.2020.402

Authors' information: Zoya Ozherelieva, PhD, Leading Researcher, orcid.org/00000002-1730-4073; Pavel Prudnikov, PhD, Senior Researcher, orcid.org/0000-00019097-8042; Marina Zubkova, Researcher, orcid.org/0000-0002-0741-4607

Manuscript Editor: Anton Nizhnikov, Department of Genetics and Biotechnology, Faculty of Biology, Saint Petersburg State University, Saint Petersburg, Russia

Received: January 22, 2020;

Revised: May 30, 2020;

Accepted: June 30, 2020

Copyright: @ 2020 Ozherelieva et al. This is an open-access article distributed under the terms of the License Agreement with Saint Petersburg State University, which permits to the authors unrestricted distribution, and self-archiving free of charge.

Funding: No funding information provided. Competing interests: The authors have declared that no competing interests exist. and early ripening of berries (Hofer, Drewes-Alwarez, Scheewe and Olbricht, 2012; Karlind et al., 2015). The constant introduction of this culture from different countries contributes to the expansion of the assortment, as well as the involvement of new genotypes in the breeding process (Mukhanin and Zhbanova, 2015). However, often the most productive, large-fruited industrial varieties have low winter hardiness. In many regions of the world, as well as in Russia, heat shortage caused by low air and soil temperatures is the main factor limiting the growth, development and productivity of plants (Khan, Fariduddin and Yusuf, 2017). Resistance to low temperatures or their daily average differences is one of the most important characteristics for strawberries in the central region of Russia. The most dangerous periods are snowless late autumn and the beginning of winter, when snow has not fallen yet and the air temperature drops to -10 or $-15^{\circ} \mathrm{C}$; in these circumstances, freezing or death of the strawberry root system is possible (Stolnikova, 2004). Alternating thaws and frosts are also dangerous for strawberry plants (Shokaeva, 2006). Provided growth ceases and the hardening phases are passed, the frost-resistant state of plants is achieved (Makarova et al., 2014). Timely hardening plays an important role for strawberry plants in winter (Rodnli, 2013).

Hardening is a complex set of physiological and biochemical processes, associated with significant dehydration of the cell and the accumulation of protective compounds (sugar, amino acids, etc.). By increasing the concentration of protective 
compounds (sugar, amino acids, etc.) and by increasing the concentration of cell sap and bound free water in the plant, hardening prevents the formation of both intracellular and extracellular ice (Kovacz et al., 2011; Turk et al., 2014; Bezirganoglu, 2017; Bezirganoglu, Uysal and Yiğit, 2018). In this regard, the state of the water regime in the autumn period and the effective accumulation of protective substances by winter are some of the important factors determining the successful wintering of plants.

The aim of the study was to find some physiological and biochemical indicators of adaptation in the autumn period and to evaluate frost resistance of strawberries of different ecological and geographical origin by artificial freezing.

\section{Material and methods}

The study on frost resistance was carried out on the basis of the VNIISPK Laboratory of Physiology of Fruit Plant Resistance in 2017-2019. The experimental station is located in the central part of the Central Russian Upland (53 $3^{\circ}$ North, $36^{\circ}$ East).

Strawberry plants were planted at the Institute's primary variety study site in 2016, in the second half of summer (end of July), according to a $90 \times 20 \mathrm{~cm}$ pattern in triplicate, 30 plants in repetition, randomized.

Varieties of strawberries of different ecological and geographical origin were used as material ('Kokinskaya rannyaya,' 'Rosinka', 'Solovushka,' 'Tsaritsa', 'Urozhaynaya TsGL' - Russia; 'Sara' — Sweden; 'Alba', 'Marmolada' Italy; 'Korona', 'Sonata' - Netherlands).

\section{Weather conditions in the autumn period (2017-2018)}

In September, according to two-year data, the average daily air temperature was normal, $14.0^{\circ} \mathrm{C}$. The minimum air temperature dropped to $-1.5^{\circ} \mathrm{C}$. The precipitation amount was $56.2 \mathrm{~mm}$. In October, the average daily air temperature was also normal, $6.0^{\circ} \mathrm{C}$; the minimum temperature dropped to $-4.8^{\circ} \mathrm{C}$. Precipitation in October was above the norm at $87.4 \mathrm{~mm}$. In November, the average daily air temperature was $1.0^{\circ} \mathrm{C}$; the minimum air temperature dropped to $-18.5^{\circ} \mathrm{C}$. The amount of precipitation was $44.9 \mathrm{~mm}$.

\section{Determination of the fractional composition of water in the leaves of strawberries in the autumn}

To study the state of the water regime of strawberries in the autumn, the fractional composition of leaf water was studied according to the Okuntsova-Marinchik method (Ozherelieva et al., 2019). This method is based on changing the concentration of sucrose solution while immersing leaf tissue in it. The bottle was weighed on an electronic scale MWP-300H (Cas, Korea), then $2 \mathrm{ml}$ of $30 \%$ su- crose solution was poured in and the bottle was weighed again. Strawberry leaves were crushed in a laboratory mill LZM-1M (Olis, Russia). Prepared leaf samples weighing $0.4 \mathrm{~g}$ were immersed in a $30 \%$ sucrose solution (in three replicates). Some of the water from the leaf tissue passed into the solution, reducing its concentration. Based on the initial volume of the solution and its initial and final concentration, the amount of water that entered the solution from leaf tissues was determined. The content of bound water was calculated from the difference in the total water content and the water that passed into the solution. The concentration of sucrose solution was determined using a PAL-1 digital refractometer (Atago, Japan). The total water content in the leaves was determined by the formula: $\mathrm{W}=\left(\mathrm{m}_{1}-\mathrm{m}_{2}\right) / \mathrm{m}_{1} \times 100 \%$, where

$\mathrm{W}$ - the total hydration from the wet mass, $\%$

$\mathrm{m}_{1}$ - the mass of crude weighed leaves, $\mathrm{g}$

$\mathrm{m}_{2}$ - mass of absolutely dry weighed leaves, $\mathrm{g}$.

To determine the absolutely dry weight, the leaves were laid out in aluminum containers and dried in an oven at a temperature of $105^{\circ} \mathrm{C}$ to constant weight.

\section{Determination of sucrose in strawberry leaves}

The amount of sucrose in the leaves was determined in three replicates based on a resorcinol reagent reaction at a wavelength of $520 \mathrm{~nm}$. For this, $0.5 \mathrm{~g}$ of the material was rubbed in $10 \mathrm{ml}$ of ethanol heated to $80^{\circ} \mathrm{C}$, and the tubes were heated in a water bath UT-4301E (Ulab, China) (at $\mathrm{t}=100^{\circ} \mathrm{C}$ ) for $10 \mathrm{~min}$. The contents of the tubes were centrifuged for $10 \mathrm{~min}$ at $7000 \mathrm{rpm}$ in centrifuge B4i (Jouan, France). Next, $50 \mu \mathrm{l}$ of $5 \mathrm{~N} \mathrm{NaOH}$ was added to $0.5 \mathrm{ml}$ of the supernatant. It was heated in a water bath UT-4301E (Ulab, China) $\left(\right.$ at $\mathrm{t}=100^{\circ} \mathrm{C}$ ) for $10 \mathrm{~min}$. After cooling, $0.5 \mathrm{ml}$ of resorcinol reagent (100 $\mathrm{mg}$ of resorcinol $+250 \mathrm{mg}$ of thiourea in $100 \mathrm{ml}$ of ice-cold $\mathrm{CH}_{3} \mathrm{COOH}$ ) and $3.5 \mathrm{ml}$ of $30 \% \mathrm{HCl}$ were added. Test tubes were heated in the bath for $10 \mathrm{~min}$. After cooling, the optical density was determined on a BioRad SmartSpec Plus spectrophotometer (BioRad, USA) at a wavelength of $520 \mathrm{~nm}$. The disaccharide content was calculated using a calibration curve constructed for pure sucrose (Ozherelieva et al., 2019).

\section{Determination of Proline Amino Acid in strawberry leaves}

The proline content was determined in three replicates by reaction with the ninhydrin reagent (Bates et al., 1973). To do this, a 500-mg leaf sample was ground in distilled water and boiled in a water bath UT-4301E (Ulab, China) $\left(\right.$ at $\left.\mathrm{t}=100^{\circ} \mathrm{C}\right)$ for $10 \mathrm{~min}$. After this, the homogenate was centrifuged at $7000 \mathrm{rpm}$ in centrifuge B4i (Jouan, France), $2 \mathrm{ml}$ of the extract was taken and $2 \mathrm{ml}$ of glacial acetic acid and $2 \mathrm{ml}$ of ninhydrin reagent $(30 \mathrm{ml}$ of 
ice-cold $\mathrm{CH}_{3} \mathrm{COOH}+20 \mathrm{ml}$ of $6 \mathrm{M} \mathrm{H}_{3} \mathrm{PO}_{4}+1.25 \mathrm{~g}$ of ninhydrin) were added, followed by boiling in a water bath UT-4301E (Ulab, China) $\left(\right.$ at $\left.\mathrm{t}=100^{\circ} \mathrm{C}\right)$ for $1 \mathrm{hr}$. The amino acid content was calculated using a calibration curve on a BioRad SmartSpec Plus spectrophotometer (BioRad, USA) constructed for pure proline at a wavelength of $520 \mathrm{~nm}$. Proline content was expressed in $\mathrm{mg}$ per $1 \mathrm{~kg}$ of wet weight (Ozherelieva et al., 2019).

\section{Preparing strawberry plants for artificial freezing}

For each variety, 20 bushes were selected for artificial freezing. We divided them into 5 bushes for each frost resistance component. One bush was taken as one repetition. Annual plants were transplanted into pots at the end of August and placed in a roofless greenhouse with automatic irrigation. This was done so that the plants would take root and undergo natural adaptation processes to seasonal changes. In early November, pots with rooted strawberry plants from the greenhouse were transferred to laboratory conditions and stored at $-2{ }^{\circ} \mathrm{C}$ (from November to February) in the CV114-S refrigeration chamber (Polair, Russia) with a relative humidity of $40 \%$. During the winter, when needed, the required number of plants was removed from the refrigerator and frozen in the PSL-2KPH climate chamber (Espec, Japan) (Ozherelieva et al., 2019).

\section{Hardening of strawberry plants before artificial freezing}

The plants were hardened before each component of frost resistance. Hardening was carried out in an PSL$2 \mathrm{KPH}$ climatic chamber (Espec, Japan). The temperature regime of hardening was 5 days at $\mathrm{t}=-3^{\circ} \mathrm{C}$ and 5 days at $\mathrm{t}=-5^{\circ} \mathrm{C}$.

\section{Modeling of damaging factors of the winter period}

The modeling of winter damaging factors was carried out in the PSL-2KPH climatic chamber (Espec, Japan). To determine the resistance of strawberry varieties to early winter frost, freezing regimes were used at the end of November, $\mathrm{t}=-15^{\circ} \mathrm{C}$ and $-20^{\circ} \mathrm{C}$ at the beginning of December. To identify the influence of a positive temperature on the frost resistance of varieties, a threeday thaw of $+5^{\circ} \mathrm{C}$ was simulated, followed by freezing at $\mathrm{t}=-10^{\circ} \mathrm{C},-15^{\circ} \mathrm{C}$ in December, January and February. Thawing was carried out at a rate of temperature increase of $5^{\circ} \mathrm{C}$ per hour until reaching $\mathrm{t}=+2^{\circ} \mathrm{C}$ in the refrigerator. Then the plants were placed in laboratory conditions for growing at $\mathrm{t}=18-20^{\circ} \mathrm{C}$. Every three days, the plants were watered. Two weeks later, damage was visually recorded (Ozherelieva et al., 2019).

\section{Damage assessment after artificial freezing}

The degree of damage to the tissues of the rhizome and buds of the branch crowns was evaluated by the degree of browning. Damaged tissue is brown or brown in various shades. Damage was evaluated in 5 -fold repetition on longitudinal and transverse sections on a scale: 0.0 points - no damage, all tissues of the rhizome and buds of the branch crowns are light; $1.0-$ minor damage, up to $10 \%$ of the tissue changed color to light yellow; 2.0 - reversible damage, up to $25 \%$ of the tissue changed color to light brown; 3.0 - rhizome and bud tissue of the branch crowns turned brown to $30-40 \%$ of the total cut area; 4.0 - tissues of the rhizome and buds of the branch crowns were damaged on more than $50 \%$ of the surface; 5.0 points - the plant died, rhizome tissue and buds of the branch crowns were dark brown (Ozherelieva et al., 2019). Frost resistance of the strawberry varieties was evaluated for each component by averaging damage points of rhizomes and branch crowns on the following scale: $0.0-1.0$ points - highly frost-resistant; 1.1-2.0 points - frost-resistant; 2.1-3.0 medium frost-resistant; $3.1-4.0$ - slightly frost-resistant; 4.1-5.0 points - non-frost-resistant.

\section{Statistical analysis}

The research results were analyzed using correlation and one-way analysis of variance (ANOVA). To evaluate the effect of genotypes, the least significant difference $\left(\mathrm{LSD}_{05}\right)$ was calculated. The results were presented as $\mathrm{M} \pm \mathrm{SEM}$.

\section{Results}

\section{Determination of the fractional composition of water in the autumn}

As a result of the experiment, it was found that in the autumn period, against the background of a decrease in the level of water content, strawberry plants are characterized by an increase in bound and a decrease in free water in leaf tissues. A high level of correlation was noted between the minimum air temperature in autumn and the water content of strawberry leaf tissue and the ratio of bound water to free water (Table 1).

Table 1. The relationship between the physiological and biochemical parameters of strawberry leaves and the minimum temperature in autumn $(\min t)$ (significant correlation at $p<0.05$ )

\begin{tabular}{l|c}
\hline $\begin{array}{c}\text { Physiological and } \\
\text { biochemical parameters }\end{array}$ & $\begin{array}{c}\text { Correlation coefficient, } \\
\text { r-Pearson }\end{array}$ \\
\hline Total leaf water content & 0.81 \\
\hline Bound water / free water ratio & -0.97 \\
\hline Amino Acid Proline & -0.98 \\
\hline Sucrose & -0.70 \\
\hline
\end{tabular}




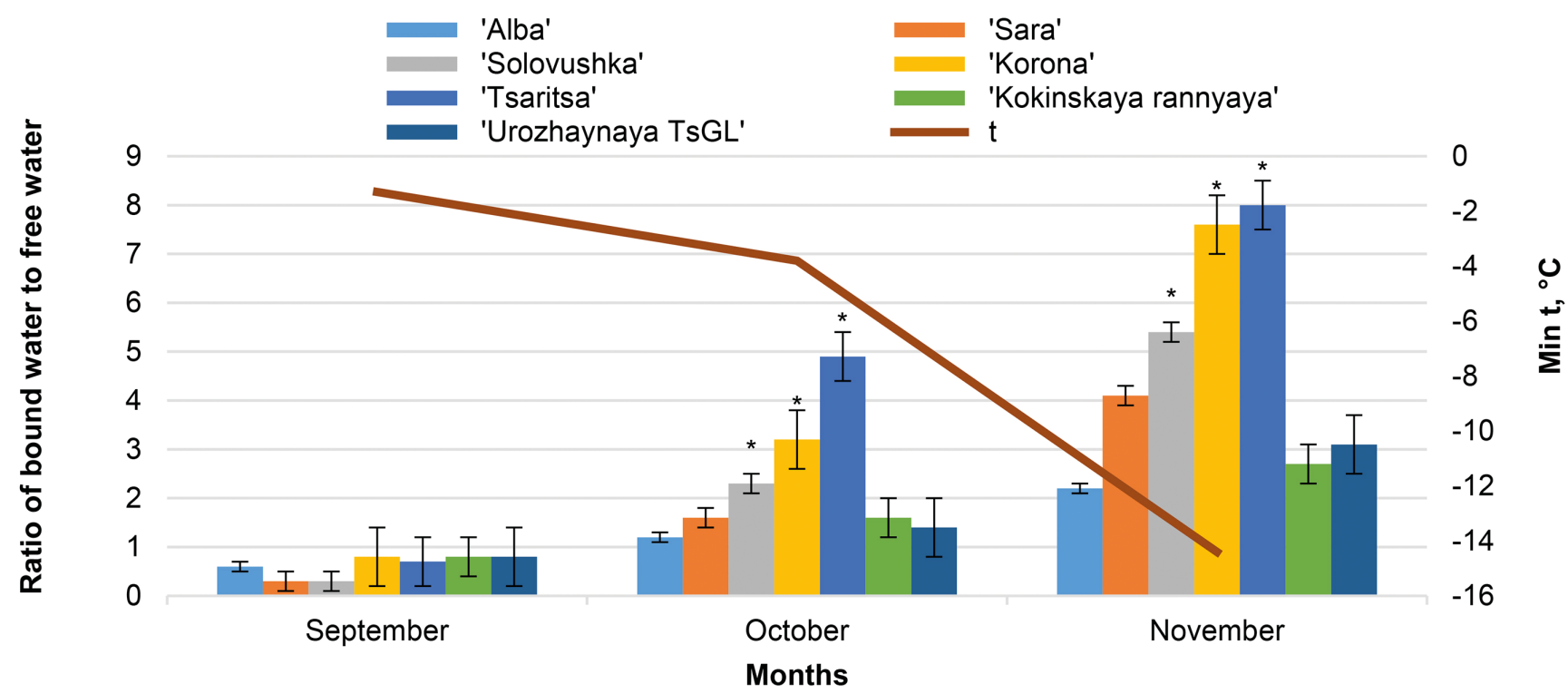

Fig. 1. The ratio of bound water / free water in the leaves of varieties of strawberry in the autumn period 2017-2018 (statistically significant differences at $\left.p \leq 0.05 \mathrm{~F}_{\mathrm{f}}=6.8>\mathrm{F}_{\mathrm{t}}=2.4\right) \mathrm{LSD}=1.4(\mathrm{M} \pm \mathrm{SEM})$

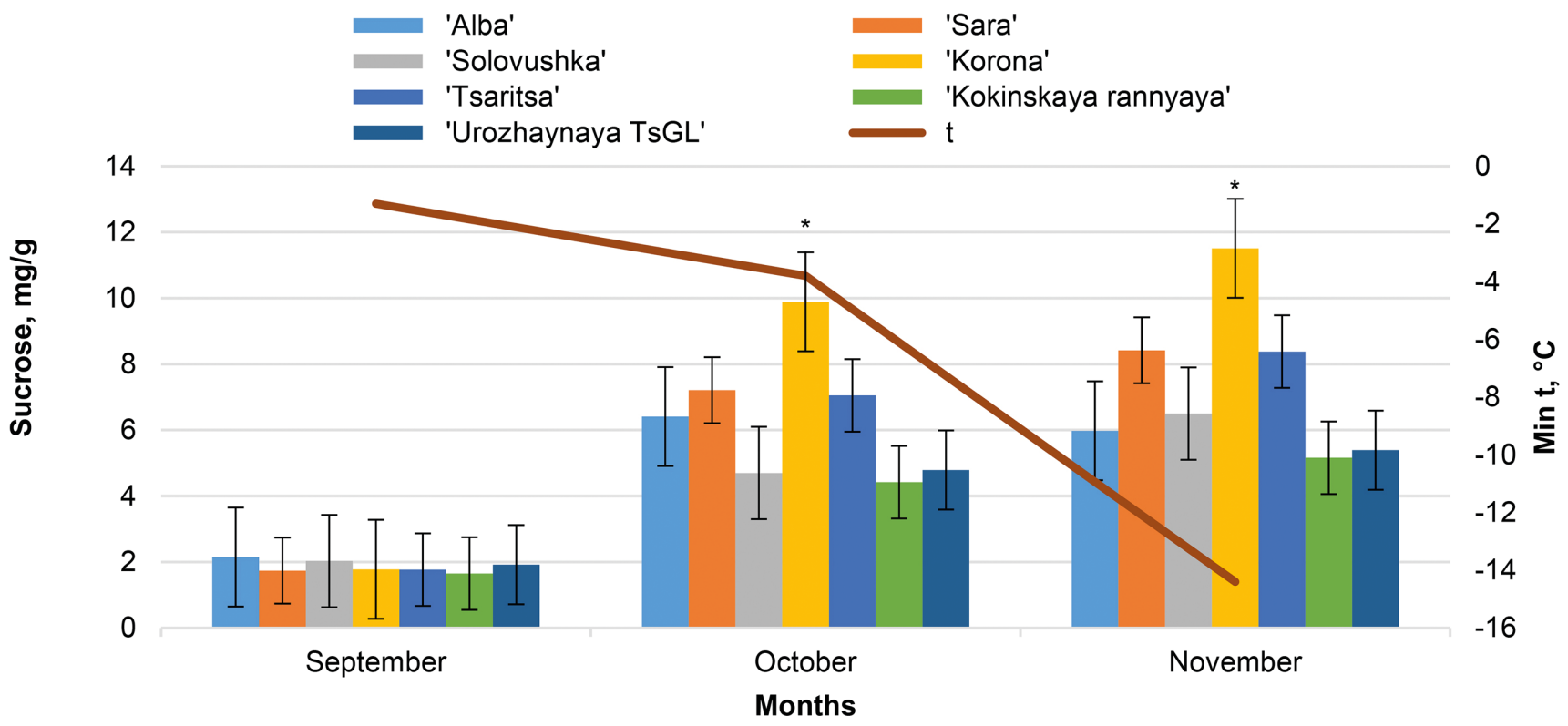

Fig. 2. Sucrose content in the leaves of strawberry plants in the autumn period 2017-2018 (statistically significant differences at $p \leq 0.05$ $\left.\mathrm{F}_{\mathrm{f}}=2.8>\mathrm{F}_{\mathrm{t}}=2.4\right) \mathrm{LSD}=2.4(\mathrm{M} \pm \mathrm{SEM})$

It is known that in winter-hardy varieties of fruit crops, the bound / free water ratio is higher than in nonhardy varieties (Krasova et al., 2014; Ozherelieva et al., 2016). Previous research of the fractional composition of water in September demonstrated that strawberry leaves have a low ratio of bound to free water. In October, the bound / free water ratio increased by 1.8 to 7.7 times. In November, it was higher (by 1.6 to 18.0 times) than in previous autumn months. At the same time, a high degree of correlation between the bound / free water ratio and the minimum air temperature was revealed (Table 1). The maximum ratio of water fractions was ob- served in the varieties 'Solovushka,' 'Tsaritsa', 'Sara' and 'Korona' (Fig. 1).

\section{Determination of sucrose in the leaves of strawberries in the autumn}

Sugars increase the water retention capacity of protoplasmic colloids, protecting against the formation of intracellular ice and excessive cell dehydration (Luo et al., 2011). The decrease in the minimum air temperature in the autumn period significantly affected the accumulation of sucrose in the leaves of strawberries (Table 1). 


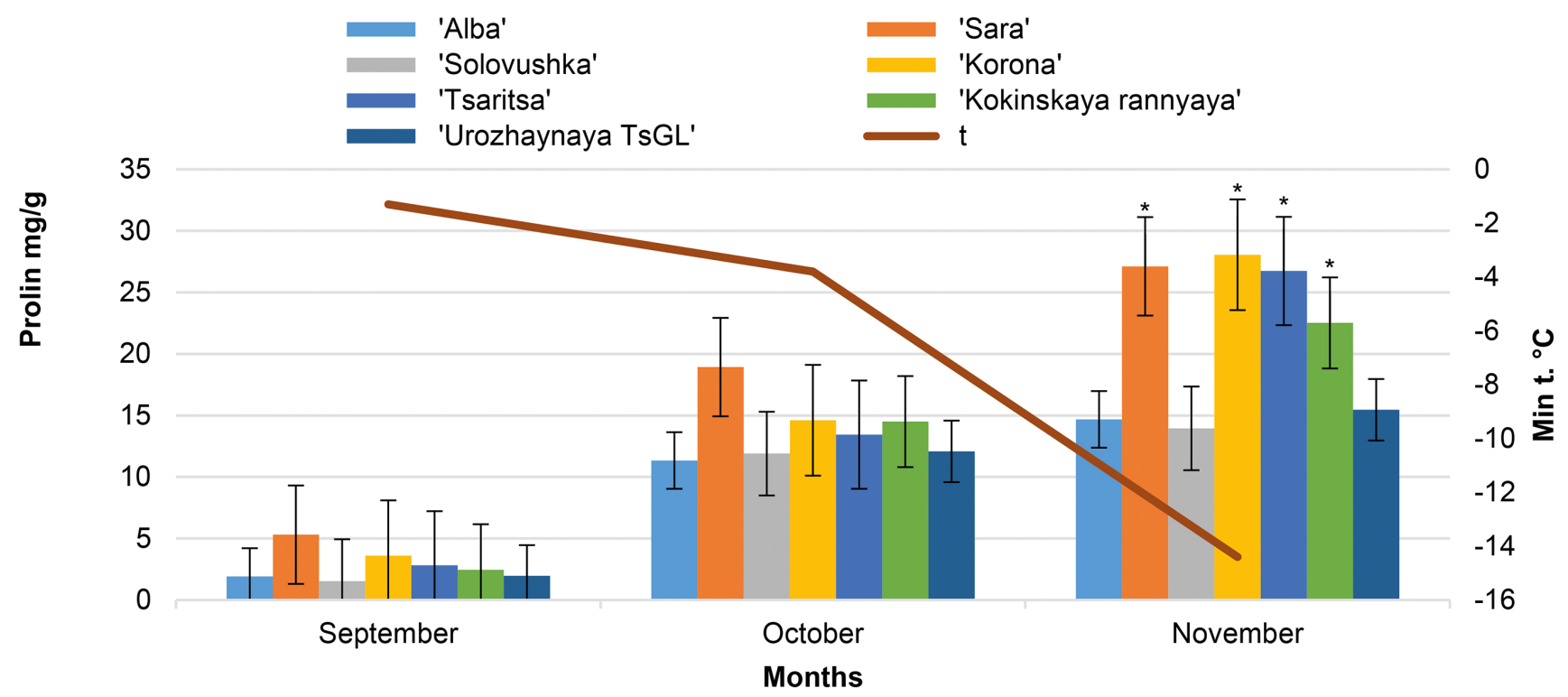

Fig. 3. The content of free proline in the leaves of strawberries in the autumn period 2017-2018 (statistically significant differences at $\left.p \leq 0.05 \mathrm{~F}_{\mathrm{f}}=7,4<\mathrm{F}_{\mathrm{t}}=2.4\right) \mathrm{LSD}=3.1(\mathrm{M} \pm \mathrm{SEM})$

During the autumn period, the sucrose content in varieties 'Sara,' 'Korona', 'Solovushka' and 'Tsaritsa' increased on average 3.20-6.47 times, and in 'Alba', 'Urozhaynaya TsGL', 'Kokinskaya rannyaya' by $2.78-3.12$ times. The analysis was carried out in three replicates (Fig. 2).

\section{Determination of proline in the leaves of strawberries in autumn}

As the minimum air temperature decreased in autumn, an increase in the proline content was noted. During cold adaptation, other authors noted an increase in the proline content in strawberry plants (Luo et al., 2011). In the varieties 'Sara,' 'Korona', 'Solovushka' and 'Tsaritsa', the accumulation of proline amino acid over the period September-November increased by 5.1 to 9.4 times; in 'Alba,' 'Urozhaynaya TsGL' and 'Kokinskaya rannyaya' by 7.7 to 9.2 times. The analysis was performed in three replicates (Fig. 3).

Correlation analysis showed a high level of correlation between the physiological and biochemical parameters of strawberries and the minimum air temperature in autumn (Table 1). In addition, a significant relationship was established between the bound / free water ratio and the proline content $(r=0.98-0.99)$ and sucrose $(r=0.72-$ 0.97). Also, a high degree of correlation was noted between the content of sucrose and proline in the leaves of strawberries in the autumn period $(\mathrm{r}=0.80-0.94)$.

\section{Study of frost resistance in early winter}

Modeling of early winter frost $t=-15^{\circ} \mathrm{C}$ at the end of November revealed varieties with a high level of frost resistance: 'Solovushka,' 'Rosinka,' 'Tsaritsa,' 'Korona' and 'Sara.' The varieties 'Alba' and 'Marmolada' exhibited average scores for damage to the branch crowns and rhizomes.
After modeling of early winter frost $\left(\mathrm{t}=-20^{\circ} \mathrm{C}\right)$ in early December, varieties with high frost resistance were identified: 'Rosinka', 'Solovushka' and 'Tsaritsa'. At $\mathrm{t}=-20^{\circ} \mathrm{C}$ in early December, frost resistance was noted with reversible damage to the branch crowns in varieties 'Sara' and 'Korona.' 'Kokinskaya rannyaya,' 'Urozhaynaya TsGL' and 'Alba' had an average level of frost resistance. The Italian variety 'Marmolada' was badly damaged. Freezing of $30 \%$ of the roots and browning of the rhizome tissues led to the death of plants of this variety (Table 2). A high degree of correlation was found between the ratio of bound water / free water and the degree of damage to strawberry plants at the beginning of winter $(r=-0.76$ at $p<0.05)$.

Table 2. The degree of damage to strawberry cultivars in early winter (2017-2018) (M \pm SEM)

\begin{tabular}{l|c|c}
\hline \multirow{2}{*}{\multicolumn{1}{c|}{ Varieties }} & \multicolumn{2}{c}{$\begin{array}{c}\text { Score damage to } \\
\text { strawberries in early winter }\end{array}$} \\
\cline { 2 - 3 } & $-15^{\circ} \mathrm{C}$ & $-20^{\circ} \mathrm{C}$ \\
\hline 'Kokinskaya rannyaya' & $0.7 \pm 0.27$ & $2.5 \pm 0.44$ \\
\hline 'Solovushka' & $0.2 \pm 0.15$ & $0.8 \pm 0.36$ \\
\hline 'Rosinka' & $0.0 \pm 0.00$ & $0.3 \pm 0.12$ \\
\hline 'Tsaritsa' & $0.0 \pm 0.00$ & $0.8 \pm 0.20$ \\
\hline 'Urozhaynaya TsGL' & $1.1 \pm 0.10$ & $2.5 \pm 0.33$ \\
\hline 'Alba' & $2.6 \pm 0.18$ & $3.0 \pm 0.41$ \\
\hline 'Marmolada' & $2.3 \pm 0.20$ & $3.5 \pm 0.31$ \\
\hline 'Korona' & $0.5 \pm 0.18$ & $2.0 \pm 0.14$ \\
\hline 'Sara' & $0.8 \pm 0.18$ & $2.0 \pm 0.33$ \\
\hline 'Sonata' & $1.0 \pm 0.01$ & $2.3 \pm 0.12$ \\
\hline LSD05 & 0.4 & 0.8 \\
\hline
\end{tabular}




\section{The study of frost resistance of strawberries during winter thaw}

The varieties 'Solovushka', 'Korona', 'Marmolada', 'Sara' and 'Sonata' showed high frost resistance in experiments with a decrease in temperature to $-10^{\circ} \mathrm{C}$ after a threeday thaw of $+5^{\circ} \mathrm{C}$ in December. In this case, reversible damage to the rhizome was observed in the varieties 'Kokinskaya rannyaya,' 'Rosinka', 'Urozhaynaya TsGL' and 'Tsaritsa'. In January, at $\mathrm{t}=-10^{\circ} \mathrm{C}$, after a three-day thaw of $+5^{\circ} \mathrm{C}$, the 'Sara' variety retained a high level of frost resistance. Varieties 'Rosinka', 'Solovushka', 'Tsaritsa,' 'Korona' and 'Sonata' had reversible damage to the rhizome. Moreover, in the varieties 'Kokinskaya rannyaya', 'Rosinka', 'Urozhaynaya TsGL' and 'Alba', damage to the rhizome and leaves intensified. 'Marmolada' showed very strong freezing damage. In February, at $\mathrm{t}=-10^{\circ} \mathrm{C}$ after a three-day thaw of $+5^{\circ} \mathrm{C}$, the varieties with reversible rhizome damage 'Solovushka,' 'Tsaritsa', 'Korona' and 'Sara' preserved frost resistance. Varieties 'Rosinka', 'Alba' and 'Sonata' showed an average level of frost resistance. Varieties 'Kokinskaya rannyaya,' 'Urozhaynaya TsGL' and 'Marmolada' were characterized by low frost resistance (Table 3).

In December, exposure to $\mathrm{t}=-15^{\circ} \mathrm{C}$ after a threeday thaw of $+5^{\circ} \mathrm{C}$ intensified freezing in the studied varieties. At the same time, frost-resistant varieties of 'Rosinka, 'Solovushka, 'Tsaritsa, 'Korona' and 'Sara' were noted. 'Kokinskaya rannyaya,' 'Urozhaynaya TsGL' and 'Sonata' varieties were characterized by an average level of frost resistance during the thaw in January. A low level of frost resistance was noted in plants of 'Alba' and 'Marmolada' varieties. In January, at the same temperature, stability was preserved by 'Solovushka', 'Tsaritsa' and 'Korona'. At the same time, frost resistance was decreased in other varieties. The average level of frost resistance of rhizomes was noted in the varieties 'Kokinskaya rannyaya', 'Rosinka' and 'Sara'. It was noted that Italian varieties after a three-day thaw at $+5^{\circ} \mathrm{C}$ and freezing at $\mathrm{t}=-15^{\circ} \mathrm{C}$ had a low level of frost resistance. The rhizome tissues of 'Alba' and 'Marmolada' plants were brown. Plants of the varieties 'Sonata' and 'Urozhaynaya TsGL' were severely affected by frost after the thaw. In February, after a three-day thaw at $+5^{\circ} \mathrm{C}$ and freezing at $\mathrm{t}=-15^{\circ} \mathrm{C}$, 'Solovushka, 'Tsaritsa' and 'Korona' plants preserved their frost resistance. In February, 'Rosinka' and 'Sara' had a medium level of frost resistance. After a three-day thaw at $+5^{\circ} \mathrm{C}$ and freezing at $\mathrm{t}=-15^{\circ} \mathrm{C}$, 'Kokinskaya rannyaya, 'Urozhaynaya TsGL' and 'Sonata' varieties were characterized by low frost resistance. At the same time, non-frost-resistant varieties 'Alba' and 'Marmolada' were defined. The rhizome tissues of the varieties 'Alba' and 'Marmolada' were brown; the plants died (Table 3).

\section{Discussion}

The frost-resistant state of plants is achieved under the condition that growth ceases, plants enter dormancy and pass through hardening phases (Morin et al., 2007). Hardening is a complex set of physiological and biochemical changes (Pearce, 2004; Kalberer et al., 2006; Charrier et al., 2015a; Arora and Taulavuori, 2016). At low temperatures, the outflow of water from the cells worsens and a lot of water appears, which then freezes inside the protoplast and can lead to cell death (Charra-Vaskou et al., 2015; Charrier et al., 2015b). Under the influence of low temperatures, a decrease in plant water content and

Table 3. The degree of damage to strawberry cultivars during winter thaw (2018-2019) (M \pm SEM)

\begin{tabular}{|c|c|c|c|c|c|c|}
\hline \multirow{3}{*}{ Varieties } & \multicolumn{6}{|c|}{ Score damage to strawberries during winter thaw } \\
\hline & \multicolumn{2}{|c|}{ December } & \multicolumn{2}{|c|}{ January } & \multicolumn{2}{|c|}{ February } \\
\hline & $+5^{\circ},-10^{\circ} \mathrm{C}$ & $+5^{\circ},-15^{\circ} \mathrm{C}$ & $+5^{\circ},-10^{\circ} \mathrm{C}$ & $+5^{\circ},-15^{\circ} \mathrm{C}$ & $+5^{\circ},-10^{\circ} \mathrm{C}$ & $+5^{\circ},-15^{\circ} \mathrm{C}$ \\
\hline 'Kokinskaya rannyaya' & $1.8 \pm 0.18$ & $2.7 \pm 0.12$ & $2.5 \pm 0.96$ & $3.0 \pm 0.43$ & $3.2 \pm 0.38$ & $3.3 \pm 0.17$ \\
\hline 'Solovushka' & $0.6 \pm 0.24$ & $1.6 \pm 0.15$ & $1.4 \pm 0.55$ & $1.9 \pm 0.08$ & $1.9 \pm 0.23$ & $2.0 \pm 0.58$ \\
\hline ‘Rosinka’ & $1.8 \pm 0.12$ & $2.0 \pm 0.01$ & $2.4 \pm 1.03$ & $3.0 \pm 0.61$ & $2.5 \pm 0.20$ & $3.0 \pm 0.50$ \\
\hline 'Tsaritsa' & $1.3 \pm 0.12$ & $1.7 \pm 0.12$ & $1.6 \pm 0.63$ & $2.0 \pm 0.21$ & $1.9 \pm 0.13$ & $2.0 \pm 0.29$ \\
\hline ‘Urozhaynaya TsGL' & $1.3 \pm 0.25$ & $3.0 \pm 0.21$ & $2.5 \pm 0.96$ & $3.3 \pm 0.58$ & $3.8 \pm 0.46$ & $3.5 \pm 0.29$ \\
\hline ‘Alba' & $2.3 \pm 0.27$ & $3.1 \pm 0.24$ & $2.7 \pm 0.62$ & $4.2 \pm 0.27$ & $3.0 \pm 0.15$ & $4.3 \pm 0.33$ \\
\hline 'Marmolada' & $0.9 \pm 0.13$ & $3.4 \pm 0.22$ & $3.3 \pm 0.75$ & $3.9 \pm 0.08$ & $3.5 \pm 0.29$ & $4.0 \pm 0.29$ \\
\hline ‘Korona' & $1.0 \pm 0.01$ & $1.3 \pm 0.12$ & $1.3 \pm 0.48$ & $2.0 \pm 0.20$ & $1.9 \pm 0.29$ & $1.9 \pm 0.17$ \\
\hline 'Sara' & $0.8 \pm 0.12$ & $2.0 \pm 0.10$ & $0.8 \pm 0.48$ & $2.4 \pm 0.08$ & $2.0 \pm 0.35$ & $2.5 \pm 0.17$ \\
\hline 'Sonata' & $0.8 \pm 0.12$ & $3.0 \pm 0.02$ & $1.6 \pm 0.63$ & $3.5 \pm 0.25$ & $2.8 \pm 0.32$ & $3.8 \pm 0.18$ \\
\hline $\mathrm{LSD}_{05}$ & 0.5 & 0.4 & 1.3 & 0.8 & 0.7 & 0.8 \\
\hline
\end{tabular}


an intensive increase in the content of osmotically active compounds, such as sugars and amino acids, were recorded (Gusta et al., 2004; Poirier et al., 2010; Charrier et al., 2013). Sugars serve as a source of energy and the most important substance that protects the protoplasm from freezing. The proline amino acid content can also serve as an indicator of the water retention capacity of plant cells. Proline, along with sugars, protects proteins from inactivation under conditions of dehydration and reduces the freezing temperature of protoplast contents. In their work, Luo et al. noted the effects of low temperature on the accumulation of proline and sugars in wild strawberry plants (2011). The accumulation of proline and sugars was recorded in different plant species under abiotic stress (Yan et al., 2002), which may indicate that osmolytes are able to increase the resistance of plants to stressful conditions (Xiong and Zhu, 2002; Prudnikov et al., 2017, 2018). According to the results of our research in the autumn period, during a decrease in the level of water content, strawberries are characterized by an increase in the ratio of bound water to free water. The change in the composition of water fractions in the leaves depended on the accumulation of sucrose and proline amino acid. A high dependence of physiological and biochemical parameters (proline, sucrose, bound and free water content) during the autumn adaptation of strawberries to the minimum air temperature was established. We noted that frost-resistant varieties 'Solovushka,' 'Tsaritsa' and 'Korona' were characterized by a maximum ratio of bound water to free, and increased accumulation of proline and sucrose. Low-temperature damage to strawberries is a serious problem in winters with light snowfall, not only in the northern and eastern regions (Stolinikova, 2014), but also in Central Russia (Ozherelieva and Zubkova, 2017; Ozherelieva, Zubkova and Krivushina, 2019a). Particularly dangerous are the daily average temperature drops in the second half of winter with little snow cover (Tyurina and Kulikov, 2006). In Central Russia in January and February, the number of days with thaws increased by $55 \%$ (Khaustovich, Pugachev and Khubulov, 2008). When the thaw sets in, the physiological and biochemical state of plants changes (Ozherelieva and Sedov, 2017; Ozherelieva and Emelianova, 2019). Under the influence of positive temperatures, plants fail to leave their dormant state in a timely manner, which leads to the activation of respiration processes and to changes in the water regime and the composition and structure of reserve substances, as a result of their consumption. These conditions lead to disruption of homeostasis and a decrease in frost resistance and a loss of productivity; simultaneous absence of snow cover leads to the death of plants. In the central region of Russia in the winters of $1986 / 87$ and $1989 / 90$, air temperature dropped as low as $-28^{\circ}$ to $-33^{\circ} \mathrm{C}$, soil between $-8^{\circ}$ to $-19^{\circ} \mathrm{C}$; roots and branch crowns were severely damaged due to the scant snow cover protecting the strawberries (Tyurina et al., 2002). At the end of November 2002, the longest frosty period for this time of year was recorded and the air temperature dropped to $-20^{\circ} \mathrm{C}$ in the absence of snow cover. As a result, most strawberry varieties had severe damage (Shokaeva, 2006). In Poland, harsh winters occur every 10-15 years, causing significant damage to strawberry plants (Masny and Żurawicz, 2014). Under the conditions of Croatia (Bogunovic et al., 2015) and Estonia, strawberries in recent years have often been damaged by low temperatures with insufficient snow cover (Kikas and Libek, 2004), which negatively affects the crop. Freezing occurs on strawberry fields in Northern Europe, such as Norway and Finland, and insufficient snow cover exacerbates this problem (Sonsteby and Karhu, 2005). In recent years, strawberries are vulnerable to winter cold due to unstable snow cover, especially at variable temperatures in Iran (Karami et al., 2019).

Visible winter damage to garden plants is assessed by the field method. So, in the climatic conditions of Estonia, new winter-hardy varieties of strawberries 'Salsa' and 'Harmonie' were isolated (Kikas et al., 2017). However, the field method has a drawback - the duration of the research. It is possible to accelerate the assessment of frost resistance of plants by testing under controlled conditions. Artificial freezing provides the ability to screen genotypes to determine the frost resistance potential of strawberries (Lindén, Palonen and Hytönen, 2002; Ozherelieva, Zubkova and Krivushina, 2019). So, under controlled conditions, Polish scientists studied the frost resistance of seven varieties of strawberries of different ecological and geographical origin and identified frost-resistant genotypes (Masny and Żurawicz, 2014). As a result of modeling the damaging factors of the winter period, Finnish scientists identified frost-resistant strawberry varieties for industrial cultivation in Finland. The obtained results indicate that frost resistance under controlled conditions is evaluated with a high degree of reliability (Palonen and Lindén, 2001, 2002; Lindén, Palonen and Hytonen, 2002). Iranian scientists evaluated the frost resistance of 21 varieties of strawberries under controlled conditions. As a result, a frost-resistant variety of strawberries 'Queen Elisa' is recommended for planting (Karami et al., 2019). Using the method of artificial freezing, we estimated the frost resistance potential of strawberry varieties of different ecological and geographical origin. A high correlation was established between the degree of freezing of strawberry plants and the fractional composition of water at the beginning of winter. In the early winter, frost resistance for strawberry varieties 'Solovushka,' 'Rosinka', 'Tsaritsa', 'Korona' and 'Sara' was observed. The ability to stably maintain frost resistance during the winter thaw was shown by the varieties 'Solovushka', 'Tsaritsa' and 'Korona'. Based on 
the assessment of plant damage, frost-resistant varieties suitable for cultivation in the middle zone of Russia were identified.

\section{Conclusions}

We determined some physiological and biochemical indicators of adaptation in the autumn period and evaluated the frost resistance of strawberries of different ecological and geographical origin by artificial freezing.

1. As a result of the experiment, it was found that an increase in bound water and a decrease in free water in the leaves in autumn are characteristic of strawberry plants against the background of a decrease in the level of total water content and on the accumulation of sucrose and the proline amino acid.

2. We developed protocols for estimation of freezing tolerance.

3. As a result of artificial freezing, frost-resistant strawberry varieties 'Solovushka', 'Tsaritsa' and 'Korona' were determined.

\section{References}

Arora, R. and Taulavuori, K. 2016. Increased risk of freeze damage in woody perennials VIS-À-VIS climate change: importance of deacclimation and response. Frontiers in Environmental Science 4:44. https://doi.org/10.3389/ fenvs.2016.00044

Bates, L. S., Waldren, R.P., and Teare, I. D. 1973. Rapid determination of free proline for water-stress studies. Plant and Soil 39:205-207. https://doi.org/10.1007/ BF00018060

Bezirganoglu, I. 2017. Response of five triticale genotypes to salt stress in in vitro culture. Turkish Journal Agriculture and Forestry 41:372-380. https://doi.org/10.3906/tar1703-103

Bezirganoglu, I., Uysal, P., and Yiğit, O. R. 2018. Cold stress resistance and the antioxidant enzyme system in Pisum sativum. The Journal of Animal and Plant Sciences 28(2):561567.

Bogunovic, I., Duralija, B., Gadze, J., and Kisic, I. 2015. Biostimulant usage for preserving strawberries to climate damages. Horticultural Science (Prague) 4(3):132-140. https:// doi.org/10.17221/161/2014-HORTSCI

Charra-Vaskou, K., Badel, E., Charrier, G., Ponomarenko, A., Bonhomme, M., Foucat, L., et al. 2015. Cavitation and water fluxes driven by ice water potential in Juglans regia during freeze-thaw cycles. Journal of Experimental Botany 67:739-750. https://doi.org/10.1093/jxb/erv486

Charrier, G., Poirier, M., Bonhomme, M., Lacointe, A., and Améglio, T. 2013. Frost hardiness in walnut trees (Juglans regia L.): how to link physiology and modelling? Tree Physiology 33:1229-1241. https://doi.org/10.1093/treephys/tpt090

Charrier, G., Ngao, J., Saudreau, M., and Améglio, T. $2015 \mathrm{a}$. Effects of environmental factors and management practices on microclimate, winter physiology, and frost resistance in trees. Frontiers in Plant Science 6:259. https://doi. org/10.3389/fpls.2015.00259

Charrier, G., Pramsohler, M., Charra-Vaskou, K., Saudreau, M., Améglio, T., Neuner, G., et al. 2015b. Ultrasonic emissions during ice nucleation and propagation in plant xylem.
New Phytologist 207:570-578. https://doi.org/10.1111/ nph.13361

Gusta, L. V., Wisniewski, M., Nesbitt, N. T., and Gusta, M. L. 2004. The effect of water, sugars, and proteins on the pattern of ice nucleation and propagation in acclimated and nonacclimated canola leaves. Plant Physiology 135:1642-1653. https://doi.org/10.1104/pp.103.028308

Hofer, M., Drewes-Alwarez, R., Scheewe, R. P., and Olbricht, K. 2012. Morphological evaluation of 108 strawberry cultivars - and consequences for the use of descriptors. Journal of Berry Research 2:191-206. https://doi. org/10.3233/JBR-2012-042

Kalberer, S. R., Wisniewski, M., and Arora, R. 2006. Deacclimation and reacclimation of cold-hardy plants: current understanding and emerging concepts. Plant Science 171:3-16. https://doi.org/10.1016/j.plantsci.2006.02.013

Karami, F., Gholami, M., Ershadi, A., and Siosemardeh, A. 2019. Evaluation of winter cold tolerance and critical temperature (LT50) estimation in 21 strawberry cultivars. Iranian Journal of Horticultural Science 49(1):79-91. https://doi.org/10.22059/ijhs.2017.213337.1060

Karlind, A., Hanhieva, K., Lehtonen, M., Karjalainen, R. O., and Sandell, M. 2015. None targeted metabolite profiles and sensory properties of strawberry cultivars grown both organically and conventionally. Agricultural and Food Chemistry 63:1010-1019. https://doi.org/10.1021/ jf505183j

Khan, T. A., Fariduddin, Q., and Yusuf, M. 2017. Low-temperature stress: is phytohormones application a remedy? Environmental Science and Pollution Research 24(27):2157421590. https://doi.org/10.1007/s11356-017-9948-7

Khaustovich, I. P., Pugachev, G. N., and Khubulov, G. D. 2008. Climate change and the need to improve the assortment and agrotechnics of growing garden crops in the Central Asian region. Problems of Agroecology and adaptability of varieties in modern horticulture in Russia, Orel, pp. 270-274. (In Russian)

Kikas, A., Arus, L., Kaldmae, H., and Libek, A.-V. 2017. Newly introduced strawberry genotypes for Nordic Baltic conditions. Horticultural Science (Prague) 44(3):141-147. https://doi.org/10.17221/52/2016-HORTSCI

Kovács, Z., Simon-Sarkadi, L., Sovány, C., Kirsch, K., Galiba, G., and Kocsy, G. 2011. Differential effects of cold acclimation and abscisic acid on free amino acid composition in wheat. Plant Science 180:61-68. https://doi. org/10.1016/j.plantsci.2010.08.010

Krasova, N. G., Ozherelieva, Z. E., Golyshkina, L. V., Makarkina, M. A., and Galasheva, A. M. 2014. Winter hardiness of apple cultivars. Orel, Russia, 184 p. (In Russian)

Linden, L., Palonen, P., and Hytonen, T. 2002. Evaluation of three methods to assess winter hardiness of strawberry genotypes. The Journal of Horticultural Science and Biotechnology 77(5):580-588. https://doi.org/10.1080/1462 0316.2002 .11511542

Luo, Y., Tang, H., and Zhang, Y. 2011. Production of reactive oxygen species and antioxidant metabolism about strawberry leaves to low temperatures. Journal Agricultural Sciences 3:89-96. https://doi.org/10.5539/jas. v3n2p89

Makarova, N. V., Strukova, A. D., and Antipenko, M. I. 2014. Comparative analysis of the chemical composition and antioxidant activity of remontant and non-remontant strawberry cultivars. Russia. Storage and Processing of Agricultural Raw Materials 9:45-48. (In Russian)

Masny, A. and Żurawicz, E. 2014. Controlled freezing as the cold temperature tolerance test for strawberry cultivars. Acta Horticultural 1049:893-896. https://doi. org/10.17660/ActaHortic.2014.1049.144 
Morin, X., Améglio, T., Ahas, R., Kurz-Besson, C., Lanta, V., Lebourgeois, F., et al. 2007. Variation in cold hardiness and carbohydrate concentration from dormancy induction to bud burst among provenances of three European oak species. Tree Physiology 27:817-825. https://doi. org/10.1093/treephys/27.6.817

Mukhanin, I. V. and Zhbanova, O. V. 2015. Modern assortment of strawberries for industrial cultivation. Russian school of horticulture. Strawberry 1:19-24. (In Russian)

Ozherelieva, Z. E., Prudnikov, P.S., and Bogomolova, N.I. 2016. Frost hardiness of introduced Sea buckthorn (Hippophae rhamnoides L.) genotypes in Central Russia. Proceedings of Latvian Academy of Sciences. Section $B$ 70(2):88-95. https://doi.org/10.1515/prolas-2016-0014

Ozherelieva, Z. and Sedov, E. 2017. Low temperature tolerance of apple cultivars of different ploidy at different times of the winter. Proceedings of Latvian Academy of Sciences. Section B 71(3):127-131. https://doi.org/10.1515/ prolas-2017-0022

Ozherelieva, Z. E. and Zubkova, M. I. 2017. Frost resistance of strawberry varieties in controlled conditions. Pomiculture and small fruits culture in Russia 48(1):183-186. (In Russian)

Ozherelieva, Z. and Emelianova, O.2019. The reaction of different Sorbus L. species to low temperatures during thaw in the Orel region. Journal of Forest Science 65(6):218-225. https://doi.org/10.17221/8/2019-JFS

Ozherelieva, Z. E., Zubkova, M. I., and Krivushina, D. A. 2019. Study of pine strawberry frost resistance by artificial freezing method. Vestnik of the Russian Agricultural Science 6:26-28. https://doi.org/10.30850/vrsn/2019/6/2628 (In Russian)

Ozherelieva, Z. E., Prudnikov, P.S., Zubkova, M. I., Krivushina, D. A., and Knyazev, S. D. 2019. Determination of frost resistance of strawberries under controlled conditions (guidelines). Orel, VNIISPK, 25 p. (In Russian)

Palonen, P. and Lindén, L. 2001. Winter hardiness of micropropagated and conventionally propagated strawberry plants. Journal of Horticultural Science and Biotechnology 76(6):685690. https://doi.org/10.1080/14620316.2001.11511432

Palonen, P. and Lindén, L. 2002. Winter survival of strawberry as affected by the type of planting material. Acta Horticulturae 567:329-332. https://doi.org/10.17660/ActaHortic.2002.567.70

Pearce, R. S. 2004. Adaptation of higher plants to freezing, in: Life in the Frozen State, eds. Fuller, B. J., Lane, N., and Benson, E.E. (Boca Raton, London, New York, Washington D. C: CRC Press), pp. 171-203. https://doi. org/10.1201/9780203647073.ch5

Poirier, M., Lacointe, A., and Améglio, T. 2010. A semi-physiological model of cold hardening and dehardening in walnut stem. Tree Physiology 30:1555-1569. https://doi. org/10.1093/treephys/tpq087

Prudnikov, P. S., Ozherelieva, Z. E., Krivushina, D. A., and Zubkova, M. I. 2017. Features of the accumulation of protective compounds and changes in the fractional composition of water in the leaves of Fragaria ananassa Duch. in autumn. Modern aspects of structural and functional biology of plants: from molecules to ecosystems: Proceedings of the Russian Scientific Conference. Orel, OGU, pp. 225-236. (In Russian)

Prudnikov, P.S., Krivushina, D. A., and Zubkova, M. I. 2018. Comparative characteristics of strawberry varieties based on the accumulation of tread compounds in the autumn period. Selection and variety breeding of garden crops 5(1):101-103. (In Russian)

Rognli, O.A. 2013. Breeding for improved winter survival in forage grasses, in: Imai, R., Yoshida, M., Matsumoto, N. (eds) Plant and Microbe Adaptations to Cold in a Changing World. Springer, New York, NY. https://doi. org/10.1007/978-1-4614-8253-6_17

Sonsteby, A. and Karhu, S. 2005. Strawberry production, growth and development in Northern climates. International Journal of Fruit Science 5(1):105-112. https://doi. org/10.1300/J492v05n01_10

Shokaeva, D. B. 2006. Biological bases and regularities of strawberry fruiting. Orel, Kartush, 183 p. (In Russian)

Stolnikova, N. P. 2014. Strawberry culture in Western Siberia. Barnaul, 182 p. (In Russian)

Tyurina, M. M., Gogoleva, G.A., Goloulina, L. K., Morozova, N. G., Echedy, Y. Y., Volkov, F. A., Arsentieva, A. P., and Matiash, N. A. 2002. The identification of fruit and berry crop resistance to stressors of the cold time in the field and controlled conditions. Moscow, VSTISP, 120 p. (In Russian)

Tyurina, M. M. and Kulikov, I. M. 2006. Methods of assessing the winter hardiness of fruit and berry plants in controlled conditions. Pomiculture and small fruits culture in Russia 16:11-17. (In Russian)

Xiong, L. and Zhu, J. K. 2002. Molecular and genetic aspects of plant responses to osmotic stress. Plant Cell and Environment 25:131-139. https://doi.org/10.1046/j.13653040.2002.00782.x

Yan, G., Liming, X., Manabu, I., and Jian, K. Z. 2002. An Arabidopsis mutation in translation elongation factor 2 causes superinduction of CBF/DREB1 transcription factor genes but blocks the induction of their downstream, targets under low temperatures. Proceedings of the $\mathrm{Na}$ tional Academy of Sciences USA 11:7786-7791. https://doi. org/10.1073/pnas.112040099 